\section{SAT0092 SUCCESS-1 IN OSTEOARTHRITIS (OA) TRIAL: CELECOXIB DEMONSTRATES SIGNIFICANTLY LOWER HEPATIC TOXICITY THAN DICLOFENAC IN THE TREATMENT OF OSTEOARTHRITIS}

IJ Goldstein, ${ }^{2} \mathrm{G}$ Singh, ${ }^{3} \mathrm{~J}$ Fort, ${ }^{3} \mathrm{~A}$ Bello. ${ }^{1}$ Internal Medicine, University of Illinois at Chicago School of Medicine, Chicago, USA; ${ }^{2}$ Internal Medicine, Stanford University School of Medicine, Palo Alto, USA; ${ }^{3}$ Internal Medicine, Pharmacia, Peapack, USA

\subsection{6/annrheumdis-2001.467}

Background Significant elevations of liver enzymes have been reported in patients taking NSAIDs. Among all NSAIDs, diclofenac and aspirin have been associated with the highest rates of liver toxicity. In previous trials with patients in the US and Canada treated for osteoarthritis (OA), the incidence of hepatic adverse events in patients receiving celecoxib 200 or $400 \mathrm{mg}$ per day was similar to placebo and significantly lower than the incidence for patients receiving diclofenac 100 or $150 \mathrm{mg}$ per day. Objectives We compared the hepatic tolerability of celecoxib and the most commonly used regimen of diclofenac in the treatment of OA of the knee, hip, or hand in 13,274 patients enrolled in SUCCESS-1, a multinational, double-blind, randomised trial.

Methods In the SUCCESS-1 in OA trial, patients with OA from Europe and South Africa, Asia, Latin America, and the US and Canada were evaluated for 12 weeks using fixed dosages of celecoxib $200 \mathrm{mg}$ per day, celecoxib $400 \mathrm{mg}$ per day, or diclofenac $100 \mathrm{mg}$ per day. Patients with pretreatment ALT or AST $>/=3 \mathrm{x}$ ULN were excluded. Laboratory tests were obtained at pretreatment and at the final visits.

Results Overall, patients were mostly female (78\%), and had a mean age of $62( \pm 10.4)$ years. Previous daily diclofenac use was comparable $(\mathrm{p}=0.57)$. Clinically meaningful elevations $(>/$ $=3 \mathrm{x}$ ULN) in ALT and AST were significantly more frequent in the diclofenac- vs celecoxib-treated patients $(\mathrm{p}<0.001)$ at 12 weeks. In parallel, physician-reported hepatic adverse events, including hepatic dysfunction and increases from pretreatment ALT and AST, were significantly more frequent in patients treated with diclofenac $(\mathrm{p}<0.01)$.

\begin{tabular}{|c|c|c|c|}
\hline & $\begin{array}{l}\text { Celecoxib } \\
200 \mathrm{mg} / \mathrm{d}\end{array}$ & $\begin{array}{l}\text { Celecoxib } \\
400 \mathrm{mg} / \mathrm{d}\end{array}$ & $\begin{array}{l}\text { Diclofenac } \\
100 \mathrm{mg} / \mathrm{d}\end{array}$ \\
\hline Laboratory value elevation & $\mathrm{n}=2988$ & $\mathrm{n}=2948$ & $\mathrm{n}=2998$ \\
\hline AST $>I=3 x$ ULN at final visit & $1(<0.1 \%)$ & $3(0.1 \%)$ & $20(0.7 \%)^{*}$ \\
\hline ALT $>I=3 \times$ ULN at final visit & $6(0.2 \%)$ & $6(0.2 \%)$ & $45(1.5 \%)^{*}$ \\
\hline \multicolumn{4}{|l|}{ Adverse events, incidence } \\
\hline $\begin{array}{l}\text { AST increased from } \\
\text { pretreatment }\end{array}$ & $11(0.3 \%)$ & $13(0.4 \%)$ & $\begin{array}{l}31(0.9 \%) \\
* *\end{array}$ \\
\hline $\begin{array}{l}\text { ALT increased from } \\
\text { pretreatment }\end{array}$ & $20(0.6 \%)$ & $15(0.4 \%)$ & $58(1.7 \%)^{*}$ \\
\hline
\end{tabular}

ULN: upper limit of normal; diclofenac vs celecoxib 200 or $400 \mathrm{mg} / \mathrm{d}:{ }^{*} \mathrm{p}<0.01$.

Conclusion Celecoxib, with its greater hepatic tolerability than the most commonly prescribed regimen of diclofenac, offers a clinical advantage over diclofenac in the management of OA patients.

Sponsored by Pharmacia Corporation and Pfizer Inc.

\section{SAT0093 SUCCESS-1 IN OSTEOARTHRITIS: CELECOXIB DEMONSTRATES SIMILAR EFFICACY TO THE CONVENTIONAL NSAIDS, DICLOFENAC AND NAPROXEN, IN PATIENTS WITH OSTEOARTHRITIS TREATED IN 39 COUNTRIES IN 6 CONTINENTS}

${ }^{1} \mathrm{G}$ Singh, ${ }^{2} \mathrm{~J}$ Goldstein, ${ }^{3} \mathrm{~J}$ Fort, ${ }^{3} \mathrm{~A}$ Bello, 'S Boots. 'Department of Medicine, Stanford University, Palo Alto, USA; ${ }^{2}$ Department of Medicine, University of Illinois at Chicago Medical School, Chicago, USA; ${ }^{3}$ Department of Medicine, Pharmacia, Peapack, USA

\subsection{6/annrheumdis-2001.468}

Background The SUCCESS-1 trial is the largest controlled study comparing celecoxib and NSAIDs. This long-term trial was intended to closely parallel clinical practice in a variety of worldwide settings to assess the overall efficacy, tolerability, and safety of celecoxib and NSAIDs with a large group of diverse physicians.

Objectives This study compared the efficacy, safety, and tolerability of celecoxib 200 and $400 \mathrm{mg}$ per day and the most commonly prescribed NSAIDs in 39 countries in the treatment of the signs and symptoms of osteoarthritis (OA) of the knee, hip, and hand.

Methods The SUCCESS-1 in OA trial is a large double-blind, randomised study conducted in patients from 1,142 centres in Europe and South Africa, Asia, Latin America, and the US and Canada. Patients were treated for 12 weeks using celecoxib (200 or $400 \mathrm{mg} / \mathrm{d}$ ) and the most common regimens of NSAIDs (naproxen $1000 \mathrm{mg} / \mathrm{d}$ in US and Canada and diclofenac $100 \mathrm{mg} / \mathrm{d}$ in all other countries). Assessments of arthritis efficacy were performed by country or region. Safety and tolerability were assessed globally.

Results Of the 13,194 intent-to-treat patients, the mean age was 62 years, and the majority were female (76\%) and caucasian (80\%). Patients in each group had comparable baseline aspirin use and history of upper GI bleeding. Arthritis assessments were based on mean changes in baseline arthritis pain by VAS and night pain at week 12. Data is presented from European countries/regions. No significant differences between celecoxib 200 $\mathrm{mg} /$ day and celecoxib $400 \mathrm{mg} /$ day compared to diclofenac 100 $\mathrm{mg} /$ day were observed. In addition, celecoxib $200 \mathrm{mg} /$ day and $400 \mathrm{mg} /$ day were similar in efficacy. Comparable efficacy between celecoxib and NSAIDs was also demonstrated in other countries/regions that participated in the study.

\begin{tabular}{|c|c|c|c|c|}
\hline & $\begin{array}{l}\text { Patient?s } \\
\text { Assessment of } \\
\text { Arthritis } \\
\text { Pain VAS, mean } \\
\text { change, } \mathrm{mm} \text { ? }\end{array}$ & & $\begin{array}{l}\text { Patient?s } \\
\text { Assessment of } \\
\text { Night } \\
\text { Pain, mean } \\
\text { change? }\end{array}$ & \\
\hline EFFICACY & $\begin{array}{l}\text { Celecoxib } 200 \text { mg/ } \\
\text { day* }\end{array}$ & $\begin{array}{l}\text { Diclofenac } \\
100 \mathrm{mg} / \text { day }\end{array}$ & $\begin{array}{l}\text { Celecoxib } 200 \text { mg/ } \\
\text { day* }\end{array}$ & $\begin{array}{l}\text { Diclofenac } \\
100 \mathrm{mg} / \text { day }\end{array}$ \\
\hline $\begin{array}{l}\text { Central } \\
\text { Europe }\end{array}$ & -22.1 & -20.4 & -0.73 & -0.69 \\
\hline Germany & -28.3 & -25.7 & -0.89 & -0.67 \\
\hline Italy & -17.6 & -20.6 & -0.50 & -0.54 \\
\hline $\begin{array}{l}\text { Nordic } \\
\text { regions }\end{array}$ & -13.4 & -14.2 & -0.36 & -0.38 \\
\hline $\begin{array}{l}\text { Spain/ } \\
\text { Portugal }\end{array}$ & -18.4 & -21.0 & -0.68 & -0.66 \\
\hline UK/Ireland & -10.9 & -11.9 & -0.33 & -0.38 \\
\hline
\end{tabular}


Conclusion This study adds substantially to the available efficacy data on celecoxib. It expands the data globally on the efficacy of celecoxib to various settings that closely follow local clinical practice. Celecoxib demonstrated similar efficacy to the most commonly prescribed regimen of diclofenac in the treatment of OA.

Sponsored by Pharmacia Corporation and Pfizer Inc.

\section{SAT0094 CELECOXIB DOES NOT INCREASE THE RISK OF CARDIAC FAILURE, OEDEMA, OR HYPERTENSION COMPARED TO NSAIDS: RESULTS FROM SUCCESS 1, A DOUBLE BLIND, RANDOMISED TRIAL IN 13,274 OA PATIENTS}

${ }^{1} \mathrm{~A}$ Whelton, ${ }^{2} \mathrm{G}$ Singh, ${ }^{3} \mathrm{~W}$ White, ${ }^{4} \mathrm{~J}$ Fort, ${ }^{4} \mathrm{~A}$ Bello. ${ }^{1}$ Universal Clinical Research Center, And, Johns Hopkins Medical School, Hunt Valley; ${ }^{2}$ School of Medicine, Stanford University, Palo Alto; ${ }^{3}$ Health Center, University of Connecticut, Farmington; ${ }^{4} \mathrm{Global}$ Medical Affairs, Pharmacia, Peapack, USA

\subsection{6/annrheumdis-2001.469}

Background COX-2 specific inhibitors have been shown to significantly reduce the risk of gastrointestinal complications compared to conventional NSAIDs, while providing equivalent efficacy. However, some recent studies have raised concerns about the cardiovascular and renal safety profile of COX-2 inhibitors. In a previous study of 7,968 patients in North America, celecoxib at supratherapeutic doses $(800 \mathrm{mg} / \mathrm{d})$ was shown not to increase the risk of hypertension, congestive heart failure, or renal adverse events compared to therapeutic doses of ibuprofen and diclofenac.

Objectives To compare the risk of congestive heart failure, oedema, and hypertension in OA patients treated with celecoxib at 200 or $400 \mathrm{mg}$ per day compared to patients taking therapeutic doses of diclofenac and naproxen in a multinational, doubleblind randomised trial (SUCCESS-1 in OA).

Methods A total of 13,274 patients from 1142 sites in 39 countries in Europe, South Africa, Asia, Latin America, and the United States and Canada were enrolled in the SUCCESS-1 trial. Patients were randomly assigned to fixed treatment regimens of celecoxib $200 \mathrm{mg}$ per day, celecoxib $400 \mathrm{mg}$ per day, or NSAIDs (naproxen $1000 \mathrm{mg}$ per day in the US and Canada and diclofenac $100 \mathrm{mg}$ per day in other regions).

Results Of the 13,194 patients randomised, 4421 and 4429 patients received 200 or $400 \mathrm{mg}$ per day of celecoxib respectively, 914 patients received $1000 \mathrm{mg}$ per day of naproxen, and 3510 patients received $100 \mathrm{mg}$ per day of diclofenac. Patients were mostly female (67\%), and $42 \%$ were 65 years or older (mean age: 62 years). Previous cardiovascular disease was comparable in each intent-to-treat group $(\mathrm{p}=0.25)$. ASA use was $7.9 \%$ and $8.0 \%$ at baseline, in the celecoxib and NSAID groups, respectively. The number of patients with cardiovascular and renal events adverse events is shown in the Table 1 below:

\begin{tabular}{|c|c|c|c|c|}
\hline & $\begin{array}{l}\text { Celecoxib } \\
(\mathrm{n}=\mathbf{8 8 0 0})\end{array}$ & $\begin{array}{l}\text { NSAID } \\
(n=4394)\end{array}$ & RR $(95 \% \mathrm{Cl})$ & $p$-value \\
\hline \multicolumn{5}{|l|}{ Intent-to-treat patients } \\
\hline Cardiac failure & $4(0.05 \%)$ & $9(0.2 \%)$ & $0.22(0.02,1.2)$ & 0.09 \\
\hline Oedema, peripheral & $129(1.5 \%)$ & $63(1.4 \%)$ & $1.0(0.74,1.5)$ & 0.91 \\
\hline Oedema, generalised & $42(0.5 \%)$ & $16(0.4 \%)$ & $1.3(0.67,2.9)$ & 0.47 \\
\hline Hypertension & $93(1.1 \%)$ & $54(1.2 \%)$ & $0.86(0.59,1.3)$ & 0.47 \\
\hline Hypertension, aggravated & $26(0.3 \%)$ & $13(0.3 \%)$ & $1.0(0.43,2.5)$ & 1.0 \\
\hline
\end{tabular}

Conclusion SUCCESS 1 provides additional evidence that celecoxib is associated with low incidence of cardiovascular or renal toxicity that is comparable to conventional NSAIDs.

Sponsored by Pharmacia Corporation and Pfizer Inc.

\section{SAT0095 COMPARATIVE BLOOD PRESSURE EFFECTS OF ROFECOXIB, CELECOXIB, AND PLACEBO IN PATIENTS WITH OSTEOARTHRITIS (OA): A RANDOMISED CONTROLLED TRIAL}

${ }^{1} \mathrm{GP}$ Geba, ${ }^{1} \mathrm{AB}$ Polis, ${ }^{1} \mathrm{ME}$ Dixon, ${ }^{1} \mathrm{TW}$ Dobbins, ${ }^{1} \mathrm{JE}$ Rush, ${ }^{2} \mathrm{MR}$ Weir. ${ }^{1}$ Merck and Co., Inc., West Point, PA, USA; ${ }^{2}$ University of Maryland, Baltimore, MD, USA

\subsection{6/annrheumdis-2001.470}

Background Dual inhibitors of cyclo-oxygenase (COX)- 1 and COX-2 can potentially induce elevation of systolic and diastolic blood pressure in some patients. This is thought to be due to COX-2 mediated effects on the nephron, influencing natriuresis. We examined the relative effect of selective COX-2 inhibitors, rofecoxib and celecoxib on blood pressure (BP) during a 6-week, placebo controlled OA efficacy trial.

Objectives

Methods 1082 patients with OA of the knee or hip, after withdrawal of previous therapy for OA, were randomised to treatment with rofecoxib $25 \mathrm{mg}$ (QD $(\mathrm{N}=471)$, celecoxib $200 \mathrm{mg}$ (QD $(\mathrm{N}=460)$ or placebo $(\mathrm{N}=151)$. Paracetamol was allowed as rescue during the trial. Treatment groups were similar in terms of age, race, gender, baseline OA severity, history of hypertension, and baseline BP. The mean age was 62 years, the majority were female. Greater than $40 \%$ in each group had a history of hypertension. BP (systolic, SBP and diastolic, DBP) was assessed at office visits at baseline, 2, 4, and 6 weeks in the sitting position after patients rested $10 \mathrm{~min}$. Relative OA efficacy was determined by $\%$ patients with good or excellent response to therapy (\%PGART) and WOMAC questionnaire at scheduled office visits over 6 weeks.

Results The percent of patients with pre-defined changes in SBP (increase $>20 \mathrm{~mm} \mathrm{Hg}$ and SBP $>140$ ) and DBP (increase $>15$ $\mathrm{mm} \mathrm{Hg}$ and DBP >90) was $9.6 \%$ for rofecoxib and $9.4 \%$ for celecoxib; $2.8 \%$ for rofecoxib and $2.0 \%$ for celecoxib, respectively compared to placebo $(3.3 \%$ systolic change and $2.0 \%$ diastolic change). Differences between coxibs and placebo were significant for SBP $(p=0.015)$; rofecoxib and celecoxib did not differ significantly from one another in terms of either SBP or DBP. There was one discontinuation due to hypertension (overall incidence $0.2 \%$ for rofecoxib, $0 \%$ for celecoxib, and $0 \%$ for placebo). Mean changes from baseline in SBP were $1.9 \mathrm{~mm} \mathrm{Hg}$ for rofecoxib. $0.2 \mathrm{~mm} \mathrm{Hg}$ for celecoxib, and $-4.3 \mathrm{~mm} \mathrm{Hg}$ for placebo, and in DBP were $0.3 \mathrm{~mm},-0.4 \mathrm{~mm}$, and $-2.6 \mathrm{~mm} \mathrm{Hg}$ respectively. Relief of night pain and\% PGART over six weeks were significantly greater for rofecoxib compared to celecoxib [night pain change from baseline: $-36.2 \mathrm{~mm}$ for rofecoxib vs $32.7 \mathrm{~mm}$ for celecoxib ( $\mathrm{p}=0.023$ ); PGART: $58.0 \%$ for rofecoxib vs $49.9 \%$ for celecoxib ( $p=0.014$ )]. In addition, although not a prespecified endpoint, rofecoxib resulted in significantly greater improvement than celecoxib in scores for each of the WOMAC composite domains (pain, stiffness, and physical function: $\mathrm{p}<0.01)$.

Conclusion Like dual COX-inhibiting NSAIDs, selective COX-2 inhibitors can induce elevations of systolic and diastolic blood pressure. Rofecoxib produced nearly identical small changes in 